\title{
Effects of thermal annealing and solvent-induced crystallization on the structure and properties of poly(lactic acid) microfibres produced by high-speed electrospinning
}

\author{
Dániel Vadas $^{1}$ (D) $\cdot$ Zsombor K. Nagy $^{1}$ (D) István Csontos ${ }^{1}$ (D) $\cdot$ György Marosi $^{1,2}$ (D) Katalin Bocz $^{1}$ (D)
}

Received: 22 July 2019 / Accepted: 10 December 2019 / Published online: 25 January 2020

(c) The Author(s) 2020

\begin{abstract}
This research concentrates on the marked discrepancies in the crystalline structure of poly(lactic acid) (PLA) nano- and microfibres, achieved by different annealing strategies. PLA nonwoven mats were produced by high-speed electrospinning. The high-speed production technique allowed the manufacturing of PLA microfibres with diameters of $0.25-8.50 \mu \mathrm{m}$ with a relatively high yield of $40 \mathrm{~g} \mathrm{~h}^{-1}$. The crystalline content of the inherently highly amorphous microfibres was increased by two methods; thermal annealing in an oven at $85{ }^{\circ} \mathrm{C}$ was compared to immersion in absolute ethanol at $40{ }^{\circ} \mathrm{C}$. The morphology of the fibres was examined by scanning electron microscopy; crystalline forms and thermal properties were assessed using X-ray diffractometry, Raman spectrometry, differential scanning calorimetry (DSC) as well as modulated DSC. As a consequence of 45-min heat treatment, the crystalline fraction increased up to $26 \%$, while solution treatment resulted in $33 \%$ crystallinity. It was found that only disordered $\alpha^{\prime}$ crystals are formed during the conventional heat treatment; however, the ethanol-induced crystallization favours the formation of the ordered $\alpha$ polymorph. In connection with the different crystalline structures, noticeable changes in the macroscopic properties such as heat resistance and mechanical properties were evinced by localized thermomechanical analysis and static tensile test, respectively.
\end{abstract}

Keywords Poly(lactic acid) $\cdot$ High-speed electrospinning $\cdot$ Polymorphs

\section{Introduction}

A wide variety of value-added biopolymer systems, that have been gaining ground in several industry segments, have to be adjusted to certain processing and application requirements. Annealing (recrystallization) is one of the frequently utilized modifications that usually takes place during or after manufacturing. By this method, the crystallinity of polymer material can be enhanced through the increased macromolecular mobility above $T_{\mathrm{g}}$. In particular, the design of poly(lactic acid) (PLA) products requires special attention to its crystalline phase mainly due to the inherently

György Marosi

gmarosi@mail.bme.hu

1 Department of Organic Chemistry and Technology, Faculty of Chemical Technology and Biotechnology, Budapest University of Technology and Economics, Múegyetem rkp. 3., Budapest 1111, Hungary

2 Budapest, Hungary slow crystallization kinetics of the polymer [1-5]. Inter alia, thermal history has a direct influence on the crystallinity of PLA and, consequently, on its properties altogether. Numerous studies showed that by exploiting the advantages of thermal annealing, Young's modulus and heat distortion temperature (HDT) can be effectively improved; moreover, even increased tensile strength and impact resistance are achievable without altering the molecular mass [6-11]. Stereochemistry also greatly affects the crystallization capability of PLA. A PLA macromolecule can form stereoisomers depending on its monomers: L, D and D-L (meso) lactide. For commercial purposes, PLA blends with a higher amount of L-lactide and a lower D-lactide content are used [8]. The properties of these semi-crystalline PLA grades can be tailored by varying the ratio of the two isomers, thus adjusting the molecular regularity of the PLA chains. By this means, a grade with lower D-lactide content has a higher maximum crystalline fraction.

Crystallization of PLA can result in three possible crystalline forms, i.e. $\alpha, \beta$ and $\gamma$. When PLA is crystallized from melt or solution, even during cold crystallization, $\alpha$ 
polymorph is developed. This is the most stable form, which turned out to be a left-handed 103 helix that packs into an orthorhombic unit cell $[12,13]$. The $\beta$ form can be obtained under more extreme conditions, e.g. by applying high drawing along with elevated temperature, and can be described with a trigonal unit cell [14-18]. The orthorhombic $\gamma$ form is produced through epitaxial crystallization [19]. During conventional PLA processing routes, $\alpha$ form is more likely to develop; therefore, from practical and scientific points of view, this crystal type is of great relevance. Even more research has been concentrating on the subject since Zhang et al. [20] reported that PLA could crystallize into a less ordered polymorph called $\alpha^{\prime}$. Subsequent studies revealed that at temperatures lower than about $100{ }^{\circ} \mathrm{C}$, the formation of $\alpha^{\prime}$ crystals is observed, and the stable $\alpha$ form crystallizes only above $140{ }^{\circ} \mathrm{C}[10,21-24]$. In the temperature range of $100-140{ }^{\circ} \mathrm{C}$, both types of crystals grow [21-23].

Nonwoven technologies and products represent a notable portion of the packaging industry, the largest single market of polymers $[25,26]$. In addition, these materials with disordered fibre arrangement represent the main component of a wide range of applications, including filtration [27, 28], absorbents [29, 30], drug delivery [31-33] and tissue engineering $[34,35]$ With respect to annealing of PLA nonwovens, heat resistance, tensile strength and modulus usually increase, while ductility reduces [36, 37]. In our previous study, melt-blown PLA nonwoven mats were used as precursors for self-reinforced composite preparation [38]. Without the recrystallization step, the inherently mainly amorphous PLA microfibres could not fulfil their reinforcing role in the composite, as they fused at the elevated temperature of hot compaction. Another popular manufacturing method to obtain micro- or nanofibrous PLA mats is electrospinning (ES) [25, 26, 28-37, 39]. Recently, high-speed electrospinning (HSES) technique has been developed to increase the productivity of this process [32, 33, 40-42]. To the best of our knowledge, the HSES concept has not yet been utilized to produce PLA fibres.

Several routes exist for tailoring the final properties of microfibrous PLA products via changes in the macromolecular structure. On the one hand, when modifying the composition, the use of organic or inorganic additives proved to be advantageous, and even stereo-complexation of PLA chains is on the table [34, 43-47]. On the other hand, postprocessing of the fibres can increase the crystallite size and can result in more organized crystals [38]. However, conventional annealing (using heat treatment without fixation) generally leads to dramatic relaxation of PLA fibres and the shrinkage of the product $[37,48]$. When annealing at $140{ }^{\circ} \mathrm{C}$, Riberio et al. [49] encountered severe deterioration of electrospun PLA fibres. Accordingly, it seems to be challenging to develop a stable $\alpha$ crystalline phase in nanoand micrometre-sized systems with such high sensibility to thermal defects. Viswanath et al. [50] also found that conventional annealing damaged the manufactured nanofibrous mats, while photothermal annealing in the presence of embedded gold nanoparticles preserved the nanostructured morphology. Besides heat treatment, Bye et al. [34] recommend the technique of vapour annealing by suspending the electrospun mat above a pool of dichloromethane. Naga et al. [51] proposed solvent-induced crystallization of amorphous PLA. Regarding nano- and microfibrous structures, the large surface area-to-volume ratio further increases the efficiency of solvent-induced crystallization. Gualandi et al. investigated the effect of ethanol disinfection on electrospun PLA scaffolds and demonstrated that the fibres' crystallinity exceeded $30 \%$ due to immersion in $37{ }^{\circ} \mathrm{C}$ absolute ethanol for more than $30 \mathrm{~min}$ [52]. Consequently, modulus and tensile strength of the electrospun mat increased by $69 \%$ and 36\%, respectively. Somord et al. [53] also used ethanol to remove residual water from electrospun PLA mats, but for some reason, they did not mention the solvent-induced crystallization effect; it is just noted that without the ethanol rinsing step, discoloration or degradation of PLA would occur in subsequent hot-pressing steps. The crystallinity of the produced self-reinforced nanocomposites increased to $35-40 \%$, accompanied by enhanced toughness.

The aforementioned modifications of nonwoven mats certainly need some sort of characterization. Thermoanalytical and morphological investigations are evident and essential routes to determine the basic properties of the product; the overall crystallinity, fibre diameters and alignment can be assessed by differential scanning calorimetry (DSC) and scanning electron microscopy (SEM), respectively [48, 49]. Nonetheless, in order to differentiate the two main crystal forms ( $\alpha$ and $\alpha^{\prime}$ ), the exact atomic coordinates in the crystal lattice and the intra- and intermolecular interactions have to be determined using more sophisticated methods. Temperature-modulated DSC (MDSC) permits the simultaneous measurement and separation of thermal events that are reversible and non-reversible at the modulation period timescale $[54,55]$. With the special concept of stochastic modulation, also known as TOPEM ${ }^{\circledR}$ technique, even the complex heat capacity is definable [56-58]. Structural analysis by X-ray diffraction method is a powerful way to obtain the atomic positions and to probe long-range order in the crystalline phase $[7,22,24,59]$. On the contrary, vibrational spectroscopy detects localized structures at the molecular scale. Among other methods, Raman microspectroscopy is a versatile technique capable of defining conformation distribution, in both amorphous and crystalline regions [60-62]. Measuring the heat deflection temperature (HDT) is a key topic when determining the effects of annealing, since recrystallized PLA products have higher HDT compared to amorphous ones [8]. However, information derived from a bulk HDT measurement (i.e. ISO 75 standard) represents a 
superposition of information from all of the constituents in a specimen; therefore, it is unsuitable for examining the heat resistance of nonwoven materials [63]. In the field of scanning probe microscopy, localized thermomechanical analysis (LTMA) offers the "micro" equivalent of thermomechanical investigation on micrometre-scale areas within a 10-20-s period [64-66]. By exploiting the high spatial resolution of this technique, the fibres themselves play the role of TMA specimens.

In the present paper, the results of the annealing modifications are described in detail for both heat and ethanol treatment of nonwoven PLA mats. Parallel recrystallization experiments were implemented on duplicate samples derived from the same high-speed electrospun PLA nonwoven. The specimens were comprehensively characterized by means of morphological, spectroscopic, thermal and mechanical testing methods. In addition to the new way of high-throughput ES manufacturing of PLA nano- and microfibres, the distinction between $\alpha$ - and $\alpha^{\prime}$-related thermal effects in the same DSC curve represents the novelty of our research, which was realized using modulated differential scanning calorimetry.

\section{Experimental}

\section{Materials}

Ingeo $^{\text {TM }}$ Biopolymer $3100 H P$-type PLA, purchased from NatureWorks LLC (Minnetonka, MN, USA), was chosen considering the $0.5 \%$ D-lactide content of the material as an advantage during crystallization. As material properties, in the product datasheet a specific gravity of $\rho=1.24 \mathrm{~g} \mathrm{~cm}^{-3}$, a crystalline melt temperature of $165-180{ }^{\circ} \mathrm{C}$ and a melt flow index (MFI) of $24 \mathrm{~g} / 10 \mathrm{~min}\left(210^{\circ} \mathrm{C} / 2.16 \mathrm{~kg}\right)$ are given by the producer.
Ethanol (99.5\%) and dichloromethane (99.0\%) were purchased from Merck Ltd. (Budapest, Hungary).

\section{Production of PLA nonwoven mats}

PLA nonwoven fibre mats were prepared by a high-speed electrospinning (HSES) set-up consisting of a stainless steel spinneret equipped with orifices $(d=330 \mu \mathrm{m})$ connected to a high-speed motor (Quick 2000 Ltd., Tiszavasvári, Hungary) [40]. $10 \% \mathrm{w} / \mathrm{v}$ PLA/dichloromethane solution was prepared in a sealable glass bottle with a magnetic stirrer, using $100 \mathrm{~g}$ of the PLA granules and $1000 \mathrm{~mL}$ solvent. The optimized composition is based on experiments conducted previously by our research group (the presentation of which is beyond the scope of this paper). The solution was fed with a flow rate of $400 \mathrm{~mL} \mathrm{~h}^{-1}$ using a peristaltic pump. $45 \mathrm{kV}$ voltage was applied to the spinneret, the rotational speed of which was fixed at 25,000 rpm. The produced PLA fibres were collected on a round metal mesh placed on the grounded metal funnel, in order to prevent the fibrous material from entering the air suction system (Fig. 1). PLA nonwoven mats weighing $\sim 20 \mathrm{~g}$ were removed from the mesh collector in 30-min time periods and placed in airtight sample bags for further processing. The experiments were performed at constant ambient temperature $\left(25^{\circ} \mathrm{C}\right)$ and at a relative humidity of $50 \pm 10 \%$. The productivity of the HSES technique reached $40 \mathrm{~g} \mathrm{~h}^{-1}$, which is 2-3 orders of magnitude higher than that of the single-needle ES technique used for PLA nano- and microfibre production until now [25, 26, 28-37, 39].
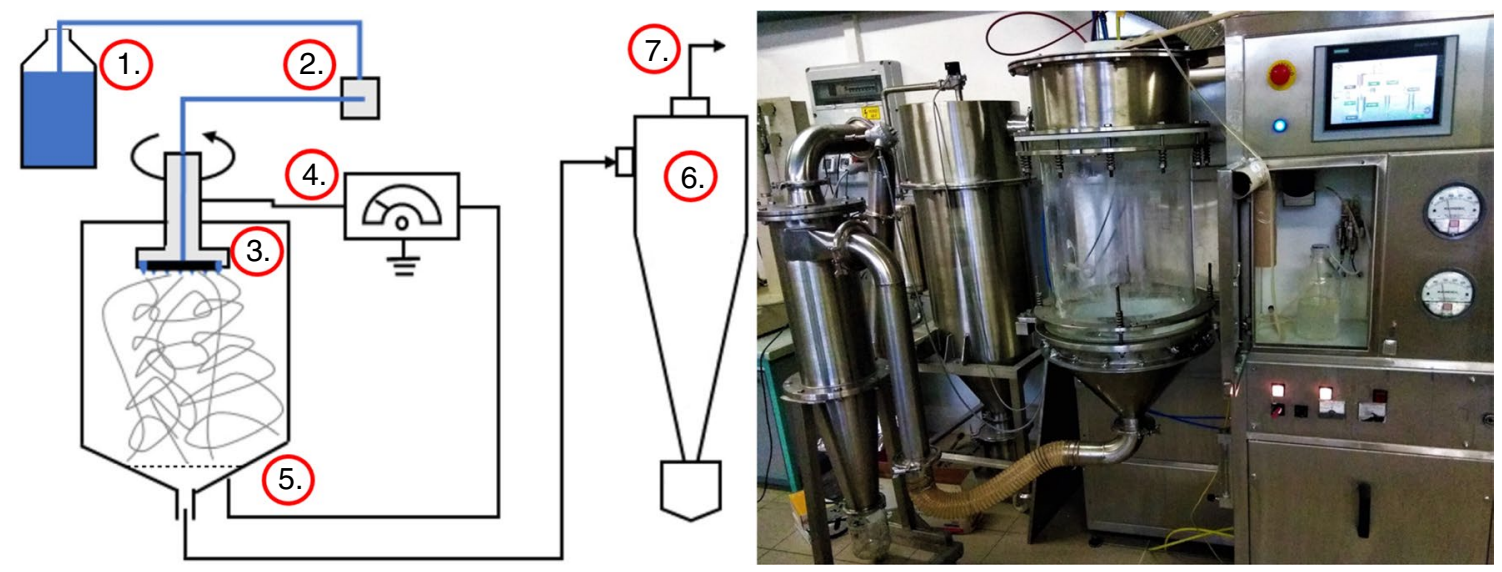

Fig. 1 Schematic illustration and a photograph of the HSES device: PLA solution (1), pump (2), spinneret (3), high voltage (4), grounded metal funnel and wire mesh (5), cyclone for collecting residual particles (6), air suction system (7) 


\section{Recrystallization methods}

\section{Thermally induced crystallization}

The obtained PLA nonwoven mats were cut into 20-mmwide and $80-\mathrm{mm}$-long strips and placed in a conventional oven for annealing at $85^{\circ} \mathrm{C}$. The sample temperature was precisely measured using a thermocouple and a digital multimeter. Samples for analyses were taken after 5, 10, 15, 20, 30, 45, 60 and 90 min and named H-5, H-10, ... H-90, respectively.

\section{Solvent-induced crystallization}

Nonwoven PLA strips of $20 \mathrm{~mm}$ wide were placed in a covered Petri dish containing 99.5\% ethanol. The solvent was previously heated and held at $40{ }^{\circ} \mathrm{C}$ on a magnetic stirrer. Samples were taken out after 3 s, 5, 10, 15, 20, 30 and 45 min (named E-5, E-10, ... E-45, respectively) and then dried under air ventilation at ambient temperature $\left(25^{\circ} \mathrm{C}\right)$.

\section{Characterization of PLA nonwoven mats}

\section{Scanning electron microscopy}

Scanning electron microscopic (SEM) images were taken from the non-treated and recrystallized fibrous mats. A JEOL JSM-5500 LV-type apparatus (JEOL Ltd., Akishima, Tokyo, Japan) was used for examination with an accelerating voltage of $15 \mathrm{keV}$. All the samples were coated with gold-palladium alloy before examination in order to prevent charge build-up on the surface. The distribution of fibre diameters was determined via measurement of at least 130 randomly selected single fibres using an image analysis software (ImageJ). One-way ANOVA was used to evaluate the statistical significance of the difference between the mean values of fibre diameters before and after thermally induced or solvent-induced crystallization $(p<0.05)$.

\section{Differential scanning calorimetry (DSC)}

A Mettler Toledo (Greifensee, Switzerland) DSC3 + type instrument was used for differential scanning calorimetry (DSC). About 6-7 mg of each nonwoven mat was compressed into a disc-shaped sample and sealed in a $40-\mu \mathrm{L}$ aluminium crucible. DSC measurements were carried out with a heating rate of $2{ }^{\circ} \mathrm{C} \mathrm{min}^{-1}$ under $50 \mathrm{~mL} \mathrm{~min}^{-1}$ nitrogen gas flow, covering a temperature range of $25-200{ }^{\circ} \mathrm{C}$. STAR ${ }^{\mathrm{e}}$ software was used to control and evaluate the measurements.

The degree of crystallinity $\left(\chi_{\mathrm{c}}\right)$ of the samples was calculated according to Eq. (1), where $\Delta H_{\mathrm{m}}$ indicates the melting enthalpy, $\Delta H_{\mathrm{cc}}$ is the cold crystallization enthalpy, $\Delta H_{\mathrm{rec}}$ is the recrystallization enthalpy, $\Delta H_{\mathrm{m} 0}\left(\alpha\right.$ or $\left.\alpha^{\prime}\right)$ is the enthalpy of melting of the $100 \%$ crystalline PLLA in $\alpha\left(143 \mathrm{~J} \mathrm{~g}^{-1}\right)$ or $\alpha^{\prime}\left(107 \mathrm{~J} \mathrm{~g}^{-1}\right)$ form, and $\Delta H_{\mathrm{c} 0}\left(\alpha\right.$ or $\left.\alpha^{\prime}\right)$ is the enthalpy of crystallization of $100 \%$ crystalline PLLA in $\alpha\left(130 \mathrm{~J} \mathrm{~g}^{-1}\right)$ or $\alpha^{\prime}\left(76 \mathrm{~J} \mathrm{~g}^{-1}\right)$ form [24].

$$
X=\left(\frac{\Delta H_{\mathrm{m}}}{\Delta H_{\mathrm{m}}^{0}(\alpha)}-\frac{\Delta H_{\mathrm{cc}}}{\Delta H_{\mathrm{c}}^{0}\left(\alpha^{\prime}\right)}-\frac{\Delta H_{\mathrm{rec}}}{\Delta H_{\mathrm{c}}^{0}(\alpha)-\Delta H_{\mathrm{m}}^{0}\left(\alpha^{\prime}\right)}\right) \times 100(\%) .
$$

\section{Modulated differential scanning calorimetry (MDSC)}

The reversing and non-reversing heat flow curves were distinguished using a DSC3 + type (Mettler Toledo AG, Greifensee, Switzerland) instrument in TOPEM ${ }^{\circledR}$ mode. The sample preparation method was identical to that of the normal DSC. Temperature-modulated differential scanning calorimetry (MDSC) measurements were implemented at an underlying heating rate of $1{ }^{\circ} \mathrm{C} \mathrm{min}-1$, from 50 to $190{ }^{\circ} \mathrm{C}$, under $50 \mathrm{~mL} \mathrm{~min}^{-1}$ nitrogen gas flow. The modulation pulse height was fixed at $0.5 \mathrm{~K}( \pm 0.25 \mathrm{~K})$, while the TOPEM ${ }^{\circledR}$ mode varied the pulse length from 15 to $30 \mathrm{~s}$. STAR ${ }^{\mathrm{e}}$ software was used to control and evaluate the measurements. A calculation window of $300 \mathrm{~s}$ was found to be appropriate for evaluation with a 3 -s shift and 90-s smoothing window. The sample response parameter was further optimized for each sample to obtain total heat flow curves similar to the normal DSC experiments.

\section{X-ray diffraction (XRD)}

X-ray reflexion diffraction patterns were recorded with a PANalytical X'Pert Pro MPD diffractometer (Almelo, The Netherlands) using $\mathrm{Cu}-\mathrm{K} \alpha$ radiation $(1.541 \AA$ ) and Ni filter. The applied current was $30 \mathrm{~mA}$, while the voltage was $40 \mathrm{kV}$. The $20-\mathrm{mm}$-wide samples were placed on a Si sheet and analysed between $2 \theta$ angles of $4^{\circ}$ and $44^{\circ}$.

\section{Raman microspectroscopy}

Raman spectra were collected from the PLA nonwoven mats using a Horiba Jobin-Yvon LabRAM (Longjumeau, France) system coupled with an Olympus BX41 optical microscope (Olympus Corporation, Tokyo, Japan) and an external $532 \mathrm{~nm}$ frequency-doubled Nd:YAG laser source. About 3-4 mg of fibrous material was compressed into a discshaped sample and placed under the objective on a microscope slide. An objective of 50× magnification was used for optical imaging and spectrum acquisition. The laser beam is directed through the objective, and the backscattered radiation is collected with the same objective. The collected radiation is directed through a notch filter that removes the Rayleigh photons, then through a confocal hole and the entrance slit onto a grating monochromator (1800 groove $\left.\mathrm{mm}^{-1}\right)$ 
that disperses the light before it reaches the CCD detector. The spectrograph was set to provide a spectral range of $100-1900 \mathrm{~cm}^{-1}$ and $4 \mathrm{~cm}^{-1}$ resolution. The acquisition time of a single spectrum was $70 \mathrm{~s}$ in each experiment, and five spectra were averaged at a time. All spectra were baseline-corrected and area-normalized within the whole wavenumber range in order to eliminate the intensity deviation between the measured points.

\section{Localized thermomechanical analysis (LTMA)}

Localized thermomechanical analyses were performed using a TA Instruments (New Castle, DE, USA) $\mu$ TA 2990 MicroThermal Analyzer equipped with a thermal probe (model 1615-00, ThermoMicroscopes, Sunnyvale, CA, USA). Twopoint calibration was implemented at room temperature using the melting temperature of a reference polyethylene terephthalate (PET) film. About 3-4 mg of fibrous material was compressed into a disc-shaped sample and placed on the sample holder using a two-sided tape. At least 10 measurements were performed to ensure reliable and reproducible results. The tip of the thermal probe was held in contact with the sample using constant force and heated from 25 to $200{ }^{\circ} \mathrm{C}$ at $10^{\circ} \mathrm{C} \mathrm{s}^{-1}$. Vertical position data of the tip were collected in the function of temperature.

\section{Tensile testing}

Static tensile tests were carried out on the recrystallized and non-treated microfibrous mats. Samples $(20.0 \mathrm{~mm} \times 2.5 \mathrm{~mm})$ of the microfibrous mats were cut and tested on a Zwick Z005 universal testing machine (Zwick GmbH \& Co. KG, Ulm, Germany). The measurements were performed using a $5 \mathrm{kN}$ load cell, with an initial grip separation of $20 \mathrm{~mm}$ and cross head speed of $5 \mathrm{~mm} \mathrm{~min}^{-1}$. All the tests were performed at room temperature at a relative humidity of $50 \pm 10 \%$. The cross-sectional area $\left(A_{0}\right)$ of the microfibrous PLA specimen was determined from the density of the PLA grade $\left(\rho=0.24 \mathrm{~g} \mathrm{~cm}^{-3}\right)$, as well as the mass $(m)$ and the exact length $(l)$ of the sample, using the following equation:

$A_{0}=\frac{\rho}{m * l}\left(\mathrm{~mm}^{2}\right)$.

Young's modulus $(E)$ and tensile stress at yield $\left(\sigma_{\mathrm{y}}\right)$ were calculated from the stress-strain curves.

\section{Results and discussion}

\section{Morphology of the PLA nonwoven mats}

SEM images were taken to investigate the effect of the two recrystallization methods on the morphology of the PLA nonwoven mats. As it can be seen in Fig. 2c, heat treatment caused a significant shrinkage of the mat, and largely curled fibres were observed already after 5 min of annealing. Increasing treatment time resulted in even stronger deformation (Fig. 2e-f). This phenomenon is due to the relaxation of oriented amorphous PLA chains at temperatures above $T_{\mathrm{g}}$ [48]. However, after immersing in $40{ }^{\circ} \mathrm{C}$ ethanol the microfibres mostly preserved their straight shape (Fig. 2b, d).

Overwhelming majority of the PLA microfibres in Fig. 2a-f are of 1-3 $\mu \mathrm{m}$ thickness (some of them ranging from 0.25 to $8.5 \mu \mathrm{m}$ ). Thus, despite the high-throughput production method, a reasonably narrow diameter distribution was obtained.

The potential effect of thermally induced and solventinduced crystallization on the fibre diameters was investigated by image analysis of SEM micrographs. The distribution of fibre diameters before and after treatments is depicted in Fig. 3. Based on the diameter analysis data, it is supposed that in the first period (5 min) of either thermal or solvent treatment the mean diameter of the fibres slightly increased, being a possible reason of the macroscopic constriction along with the curling of the microfibres. One possible explanation for this result is the chain relaxation of PLA macromolecules during treatment; practically, after the beginning of the segment movement allows the contraction of the oriented chains along the longitudinal axis of the fibre. One-way ANOVA was implemented to evaluate the statistical significance of the difference between the mean values, and we could reject the null hypothesis $(p=0.00017)$ that the mean values of the fibre diameters are equal $\left(\mathrm{H}_{0}\right.$ : $d_{\mathrm{NT}}=d_{\mathrm{E} 5}=d_{\mathrm{H} 5}$ ). It was found that the increase in fibre diameters of the thermally annealed mat is greater than that of the ethanol-treated samples which is in accordance with the greater shrinkage and more curly character of the H-5 mat as observed during SEM inspection (Fig. 2). After $45 \mathrm{~min}$ of treatments (E-45 and $\mathrm{H}-45$ ), however, a slight decrease in the fibre diameters was revealed compared to the short-time treated fibres (E-5 and H-5), which is attributed with the increasing crystalline contents.

\section{Thermal characterization using DSC and MDSC}

As the conventional DSC analysis revealed, the crystallization during the solvent-assisted treatment (ethanol, $40{ }^{\circ} \mathrm{C}$ ) fundamentally differs from that of conventional annealing at $85^{\circ} \mathrm{C}$ (Fig. 4a, b).

Regarding the curve of non-treated reference PLA mat, a significant cold crystallization exotherm $\left(T_{\mathrm{cc}} \sim 70\right.$ to $\left.90{ }^{\circ} \mathrm{C}\right)$ can be observed right after the thermal effect of $T_{\mathrm{g}}$. A single melting endothermic peak is visible at $174.2^{\circ} \mathrm{C}$ (along) with a recrystallization exotherm around $159^{\circ} \mathrm{C}$ corresponding to the crystal rearrangement and perfection of the less ordered $\alpha^{\prime}$ to the thermodynamically more stable $\alpha$ crystals, 
Fig. 2 SEM micrographs of the PLA nonwoven mats, NT (a), E-5 (b), H-5 (c), E-45 (d), H-45 (e), $\mathrm{H}-90$ (f)
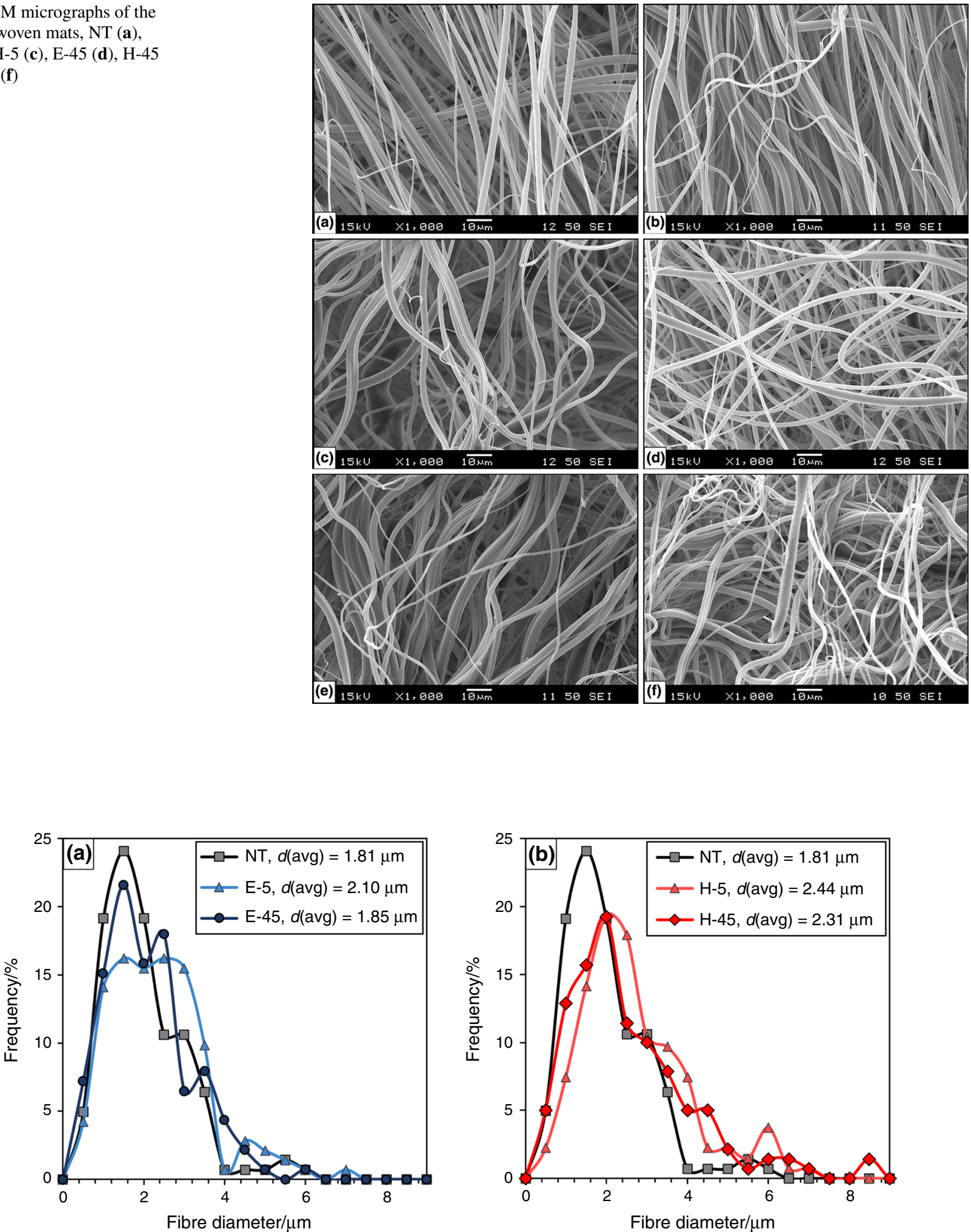

Fig. 3 Diameter distribution of fibres before (NT) and after $\mathbf{a}$ ethanol immersion and $\mathbf{b}$ thermal annealing 

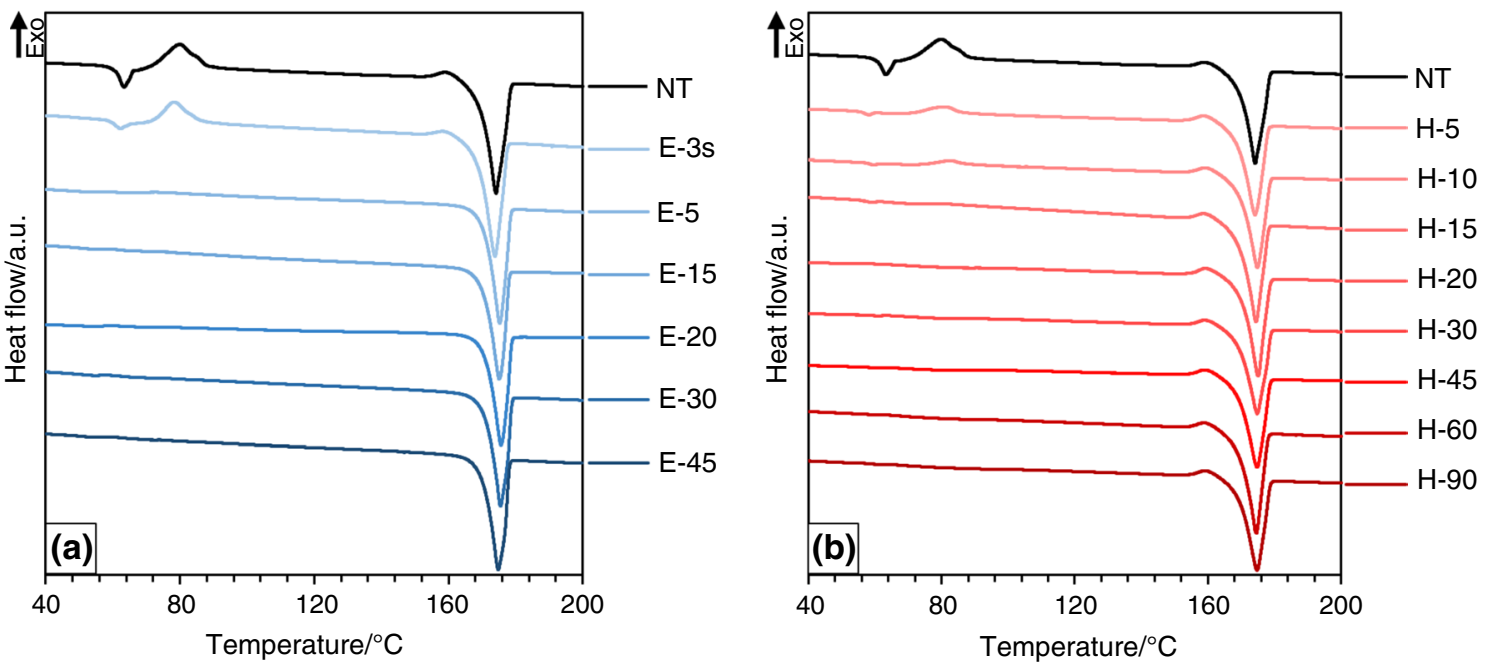

Fig. 4 DSC curves of $\mathbf{a}$ ethanol-treated $\left(40^{\circ} \mathrm{C}\right)$ and $\mathbf{b}$ heat-treated $\left(85^{\circ} \mathrm{C}\right.$

${ }^{\circ}$ C) PLA nonwoven mats

according to the related literature $[22,67]$. The main difference between the recrystallization methods is the presence of this recrystallization effect anticipating two distinct crystalline forms. On the one hand, each heat-treated sample (H-5-H-90, Fig. 4b) shows this relatively small exotherm before the crystalline melting peak; on the other hand, it utterly disappears after 5 -min immersion in $40{ }^{\circ} \mathrm{C}$ ethanol (Fig. 4a). Based on these results, it can be presumed that the ethanol solvent favours the formation of $\alpha$ crystals; however, conventional annealing at $85{ }^{\circ} \mathrm{C}$ only results in less ordered $\alpha^{\prime}$ crystals. The cold crystallization exotherm around $70-90{ }^{\circ} \mathrm{C}$ is still noticeable in the case of $\mathrm{H}-5$ and $\mathrm{H}-10$ samples, indicating a rather moderate pace of crystallization in the conventional oven compared to the ethanol-aided treatment.

The degree of crystallinity of the PLA nonwoven mats, calculated based on the DSC curves, is presented in Fig. 5. As it can be seen, all along the ethanol-induced recrystallization the samples have significantly higher crystallinity than their heat-treated counterparts. It is assumed that due to the plasticizing effect of ethanol, the increased mobility of polymer chains facilitated the formation of the thermodynamically more stable $\alpha$ crystals [51, 52]. After $45 \mathrm{~min}$, conventional heat treatment resulted in samples revealing as high as $26 \%$ degree of crystallinity, but eventually ended up underperforming the samples soaked in ethanol, the crystallinity of which exceeded $30 \%$ already after $5 \mathrm{~min}$. This advantage of ethanol treatment is also attributed to the fast diffusion of the solvent in $0.25-8.50-\mu \mathrm{m}$-thick fibres allowing the immediate solvent-induced crystallization of PLA.

The main goal of the MDSC measurements was the investigation of overlapping thermal effects by means of separating the heat capacity-dependent and kinetic changes within the fibres. The special approach of TOPEM $^{\circledR}$ technique, a

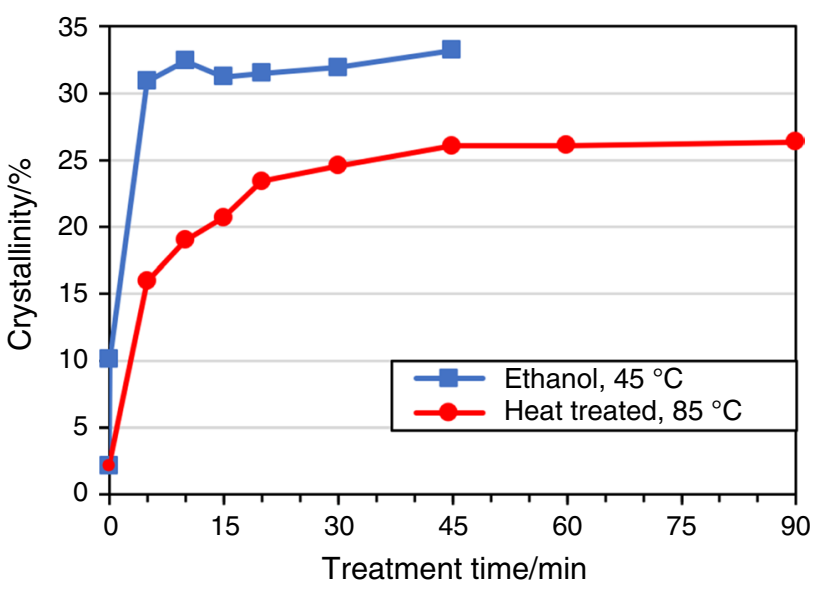

Fig. 5 Effect of ethanol-induced crystallization and thermal annealing on the crystallinity of PLA microfibres

stochastic function, is used for temperature modulation. During evaluation, a correlation analysis of the measured heat flow and the heating rate is carried out. The non-reversing heat flow is directly determined and can be associated with latent heat flow, while the reversing heat flow is calculated and can be linked to sensible heat flow. The sum of the two is the total heat flow [56].

A temperature-modulated DSC curve of the non-treated sample is displayed in Fig. 6 with the obtained non-reversing heat flow as well as the calculated reversing and total heat flow curves. The cold crystallization exotherm $\left(70-85{ }^{\circ} \mathrm{C}\right)$ is clearly visible in the non-reversible heat flow, right after the relaxation of PLA fibres $\left(58-62^{\circ} \mathrm{C}\right)$. Figure 7 allows us to observe these phenomena at higher resolution. Relaxation is only possible if the macromolecule segments have enough mobility to settle back to a more stable conformation, just 
Fig. 6 MDSC curve of the NT sample with the resulting reversible, non-reversible and total heat flow curves

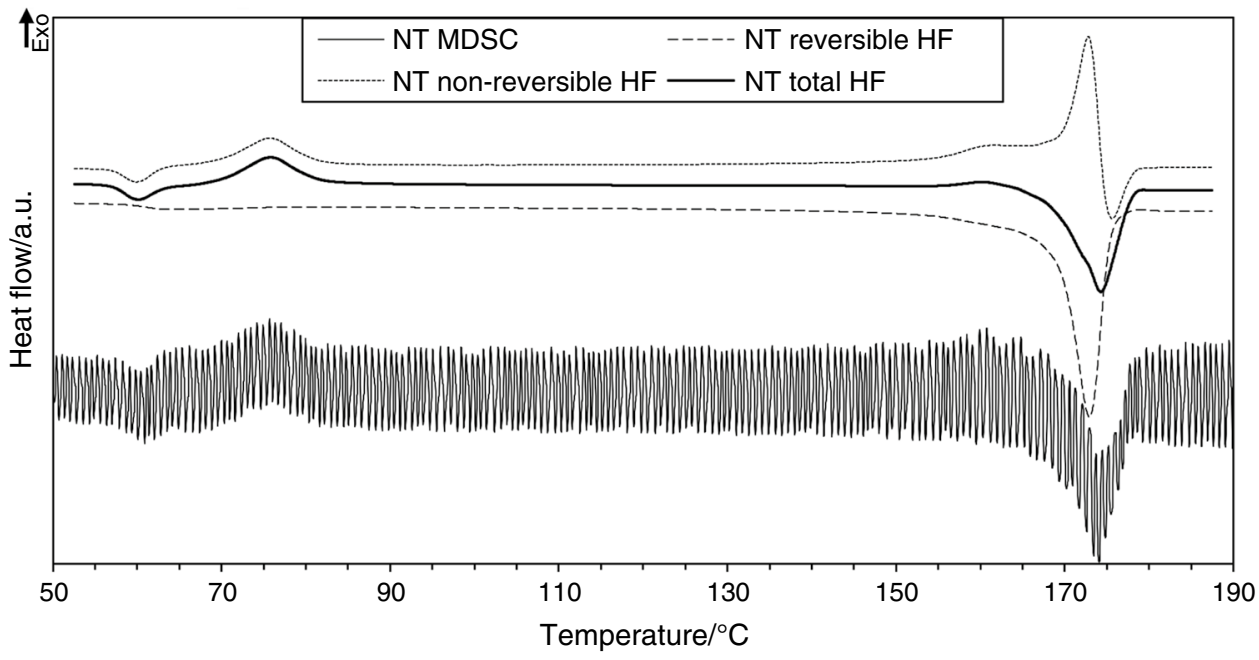

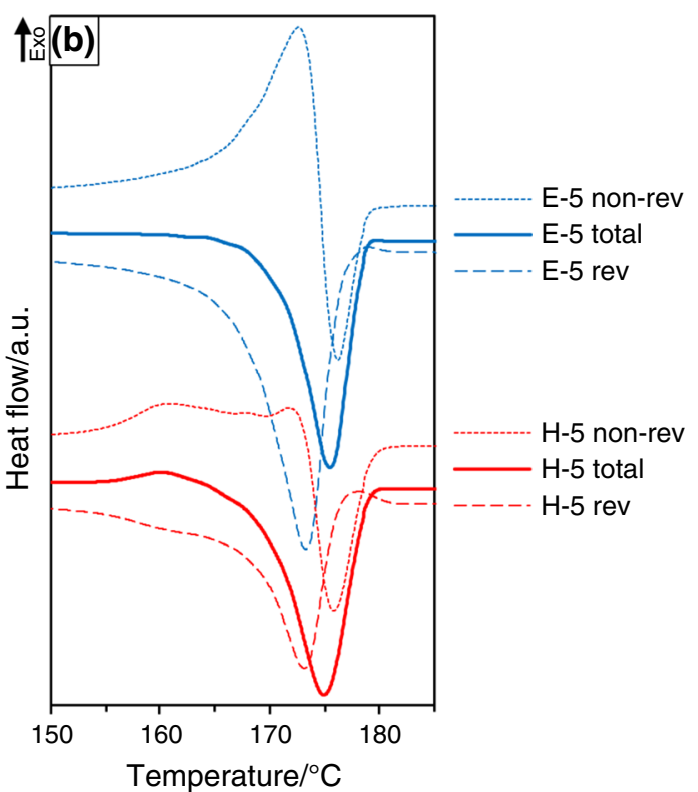

Fig. 7 MDSC curves in the temperature ranges of a $50-90{ }^{\circ} \mathrm{C}$ and $\mathbf{b} 150-185^{\circ} \mathrm{C}$

after the temperature exceeds the $T_{\mathrm{g}}$. The step of $T_{\mathrm{g}}$ takes place in the reversing curve; thus, it can be separated from the relaxation exotherm. Based on the data of Fig. 7a, it can be concluded that 5 min of heat treatment reduces the $T_{\mathrm{g}}$ and the relaxation temperature by about $5{ }^{\circ} \mathrm{C}$. This is presumably caused by increasing D-lactide content within the amorphous phase since the lamella thickening and crystalline reorganization process uses up free L-lactide units as building blocks [68].

In the case of the reference PLA nonwoven (NT) and the heat-treated (H-5-H90) samples, the recrystallization of the less ordered $\alpha^{\prime}$ to the thermodynamically more stable $\alpha$ crystals can be separated into two processes (Fig. 7b). In the non-reversing curve, the melting of $\alpha^{\prime}$ crystals can be observed; meanwhile, in the reversing heat flow curve, the crystallization of $\alpha$ crystals is noticeable. The small exothermic peak around $160{ }^{\circ} \mathrm{C}$ is their sum, as it can also be seen in Eq. (1). The lack of the recrystallization exotherm confirms the ordered $\alpha$ structure of the ethanol-immersed samples, even after 5 min of treatment.

\section{Structural characterization of the PLA microfibres}

\section{X-ray diffraction (XRD) measurements}

$\mathrm{X}$-ray diffraction measurement is one of the few characterization techniques that are able to differentiate the $\alpha$ and $\alpha^{\prime}$ crystalline phases; accordingly, this technique evinced 
clear structural differences between the PLA nonwoven mat samples treated by the two recrystallization methods. Figure 8a shows the formation of different crystalline structures as a function of treatment time. In contrast to the diffraction pattern of the NT sample, two strong reflections at $2 \theta=16.8^{\circ}-17.0^{\circ}$ and $2 \theta=19.0^{\circ}-19.2^{\circ}$ are observed for all the recrystallized samples. The reflection intensities are in accordance with the trend of the crystallinity values in Fig. 5. While crystallization during conventional annealing at $85{ }^{\circ} \mathrm{C}$ progresses quite slowly, solvent-treated samples reach their maximum crystalline content within 5-10 min. Even $3 \mathrm{~s}$ of immersion in $40^{\circ} \mathrm{C}$ ethanol actively promoted the formation of crystallites. With regard to ethanol-treated samples, a slight shift in these two main reflections is in evidence. In Fig. 8a, the differences between the two approaches of recrystallization can be examined in detail. Indexing of the observed reflections, based on the crystal structures reported for the $\alpha$ and $\alpha^{\prime}$ polymorphs, is shown as well [22, 24, 69]. For comparison, the diffraction patterns of E-45 and $\mathrm{H}-45$ samples are normalized using the strongest 110/200 reflection intensity. In Fig. 8b, the changes in the peak positions of the 110/200 and 203 reflections are more visible, indicating the two distinct crystalline structures of $\alpha$ and $\alpha^{\prime}$ phases. Moreover, ethanol-treated samples exhibit the 210 peak at $2 \theta=22.8^{\circ}$, which is also strong evidence of the more ordered polymorph. Hence, it was evinced that the ethanol solvent actively induces the formation of $\alpha$ crystals, while conventional heat treatment at $85{ }^{\circ} \mathrm{C}$ only results in less ordered $\alpha^{\prime}$ crystal structure with a rather moderate pace.

\section{Raman microspectroscopic characterization}

Raman microspectroscopy was used for structural analysis of the single fibres of the non-treated, heat-treated and solvent-treated electrospun PLA mats, respectively. In Fig. 9, higher crystallinity of both types of treated fibres compared to the non-treated PLA fibres is revealed by the increased intensity of the crystallinity-sensitive peak at $923 \mathrm{~cm}^{-1}$ and by the changes of the relative intensity of the bands in the $360-460 \mathrm{~cm}^{-1}$ region [62].

Although the two crystalline forms $\alpha$ and $\alpha^{\prime}$ have similar Raman features, some differences can be seen in the $200 \mathrm{~cm}^{-1}$ region as shown in Fig. 10a. In the spectrum collected from the thermally annealed PLA fibre (H-90), the greater degree of disorder of the $\alpha^{\prime}$ phase results in lowering in the frequency of the $200 \mathrm{~cm}^{-1}$ band [60]. On the other hand, the presence of triplet in the carbonyl stretching region (Fig. 10b) indicates the predominance of $\alpha$ crystals in the ethanol-treated fibre (E-45). The Raman spectroscopic analysis of fibres confirmed that the two types of post-crystallization processes result in different crystalline structures; thermal annealing at $90^{\circ} \mathrm{C}$ results in $\alpha^{\prime}$-rich structure, while ethanol immersion favours the formation of more ordered $\alpha$ crystalline structure, as also found based on DSC and XRD measurements carried out on the nonwoven mats. It has to be noted that the more ordered $\alpha$ crystalline structure of PLA can also be obtained by thermal annealing when carried out at higher temperature (above $140{ }^{\circ} \mathrm{C}$ ), but this method is not feasible in the case of microfibrous mats as the
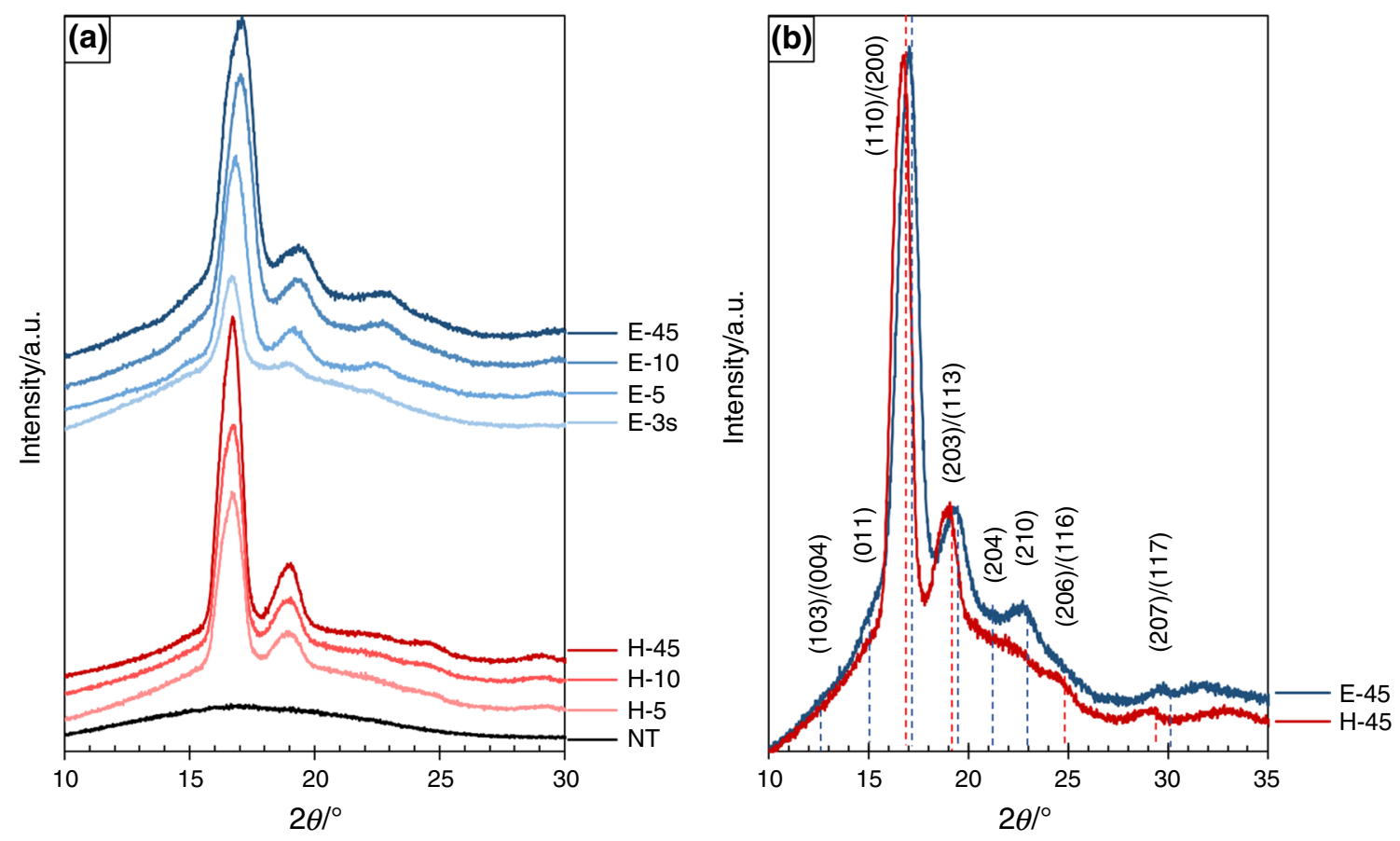

Fig. 8 XRD patterns of the PLA nonwoven mats: a effect of treatment time (0-45 min), b effect of treatment type (i.e. ethanol, heat treatment) 
Fig. 9 Raman spectra of nontreated PLA fibres (NT), effect of heat treatment $\left(\mathrm{H}-90: 85^{\circ} \mathrm{C}\right.$, $90 \mathrm{~min})$ and ethanol-assisted crystallization (E-45: $40{ }^{\circ} \mathrm{C}$, $45 \mathrm{~min})$

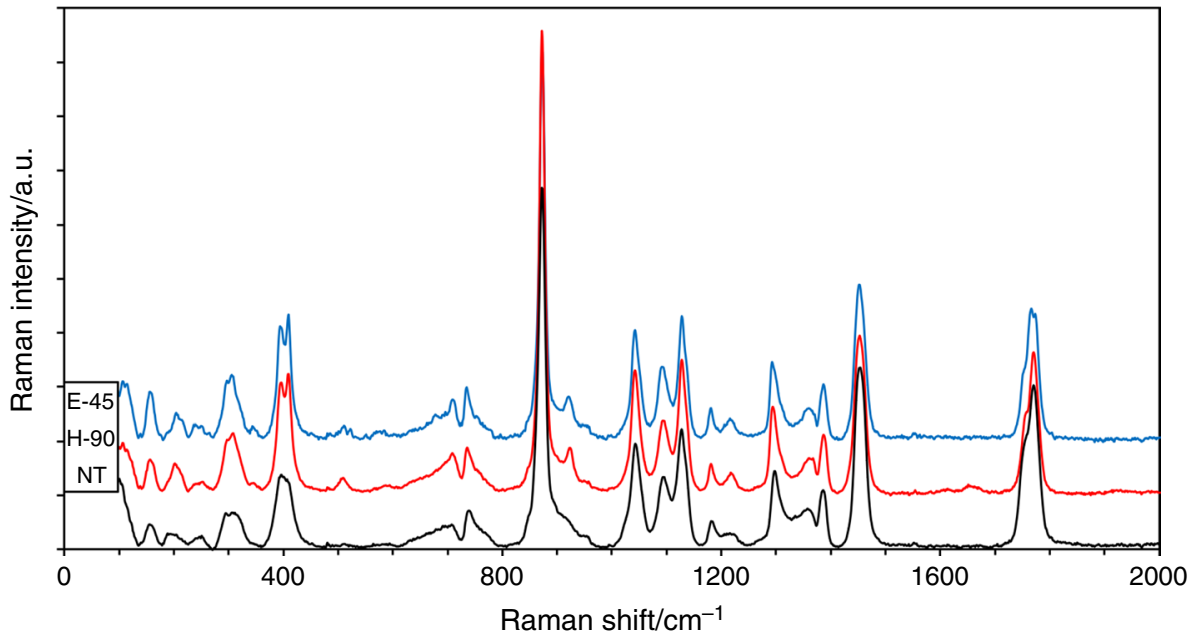

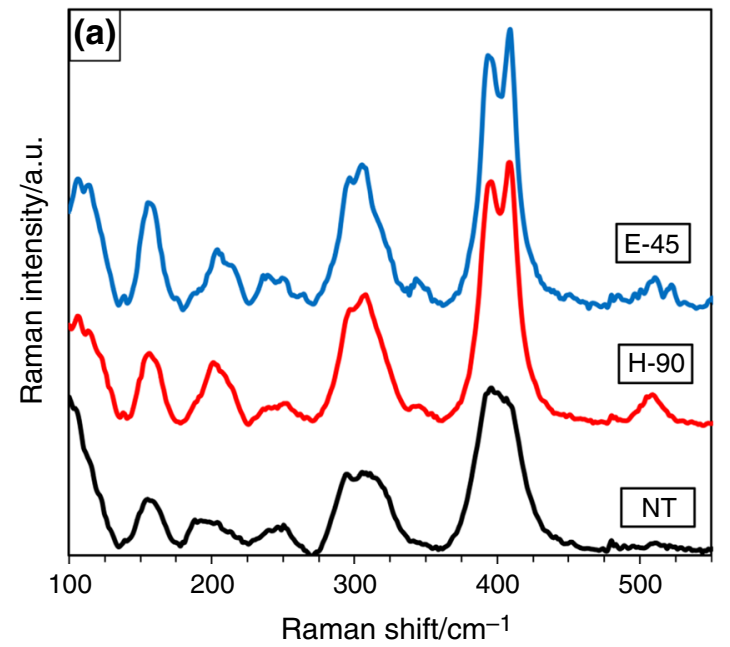

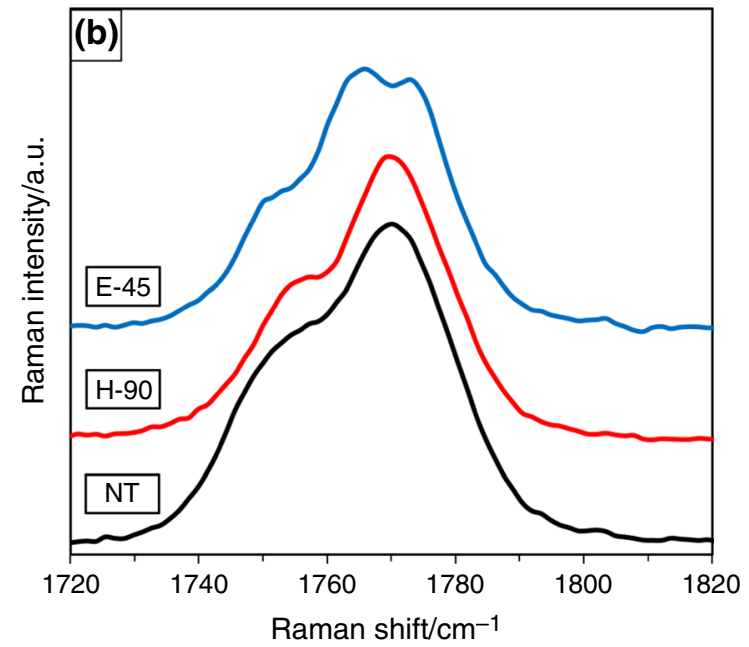

Fig. 10 Differentiation between $\alpha$ (E-45) and $\alpha^{\prime}$ (H-90) crystalline structures via Raman spectroscopy: a $100-550 \mathrm{~cm}^{-1}$ and b $1720-1820 \mathrm{~cm}^{-1}$ ranges

high-temperature annealing would cause fusion of the fibres [36, 48, 49]. Raman spectroscopic analysis, in contrast to XRD method, can be applied for in-line characterization of the crystalline structure of PLA products.

\section{Thermomechanical and mechanical properties}

\section{Localized thermomechanical analysis (LTMA)}

For the comparison of thermomechanical properties of the high- $\alpha$-crystalline-containing ethanol-treated mats, the heat-treated samples consisting of $\alpha^{\prime}$ crystals and the mostly amorphous non-treated fibrous material, LTMA measurements were implemented. Three of the measured thermomechanical curves are shown in Fig. 11 as the most characteristic results of the LTMA tests. A significant deflection

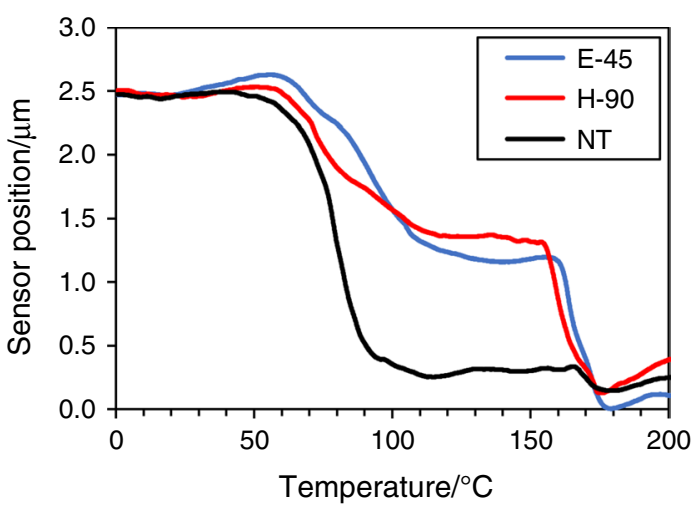

Fig. 11 Localized thermomechanical curves of PLA fibre mats (NT: non-treated, H-90: heat treatment at $85{ }^{\circ} \mathrm{C}$ for $90 \mathrm{~min}, \mathrm{E}-45$ : ethanolassisted annealing at $40^{\circ} \mathrm{C}$ for $45 \mathrm{~min}$ ) 
of the probe occurs following the $T_{\mathrm{g}}\left(\sim 55^{\circ} \mathrm{C}\right)$ of the PLA polymer; the effect is more pronounced and takes place earlier in the case of the NT sample. The result of the different crystallization methods can also be seen in the figure; the load-bearing capacity of E-45 and H-90 samples is considerably higher due to the larger degree of crystallinity. The second remarkable deflection appears around the crystalline melting temperature $\left(155-165^{\circ} \mathrm{C}\right)$. The $\mathrm{H}-90$ sample containing less ordered $\alpha^{\prime}$ crystals begins to melt at a lower temperature; however, the deflection of the H-90 and E-45 samples is about the same order of magnitude. A small diversion on the curve of the NT sample is also noticeable, meaning that the fibres inherently developed some degree of crystallinity during the high-speed electrospinning process. As the heating rate of this measurement is $10{ }^{\circ} \mathrm{C} \mathrm{s}^{-1}$, cold crystallization is out of question in this case. The evinced increased heat deflection temperatures of the recrystallized PLA microfibres are accompanied with better heat stability which can be of key importance in a large variety of potential applications where the PLA nonwovens may be

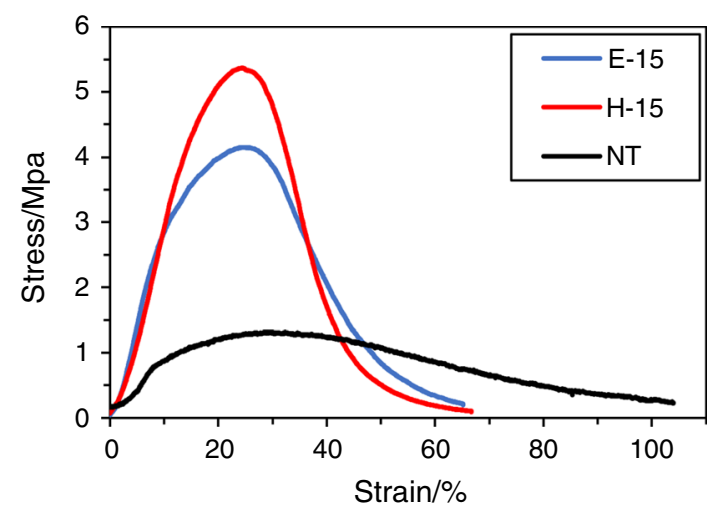

Fig. 12 Stress-strain curves of the PLA nonwoven mats

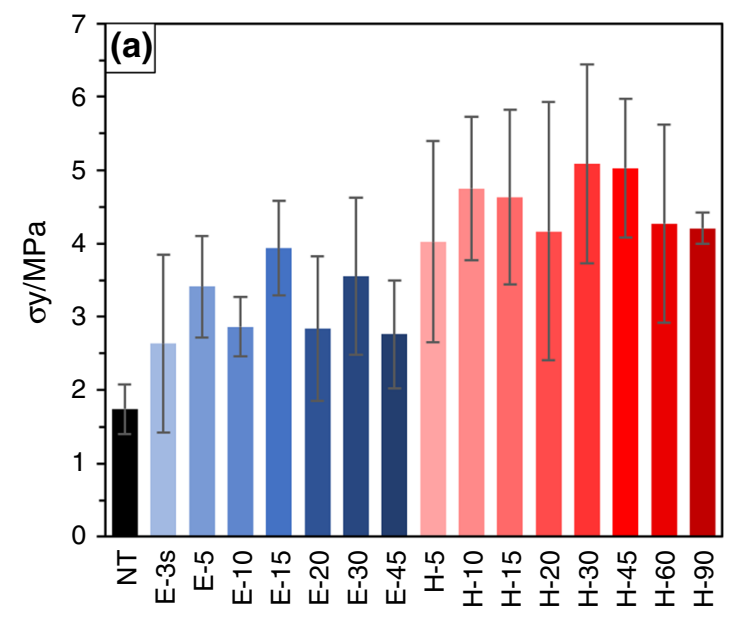

exposed to elevated temperatures (such as scaffold sterilization, high-temperature filtration, etc.). From this respect, the ethanol-induced crystallization resulting in higher crystalline fraction composed of ordered $\alpha$ crystals seems to be more advantageous.

\section{Static tensile tests}

In Fig. 12, typical stress-strain curves of the non-treated microfibrous PLA mats, as well as the E- 15 and H-15 samples, were plotted together to display differences in general. The effect of both recrystallization methods manifests itself quite obviously; tensile strength and Young's modulus increased significantly, with adverse consequences on ductility.

The outcome of conventional heat treating is more remarkable; the tensile strengths at yield $\left(\sigma_{\mathrm{y}}\right)$ of these nonwoven mats are about $30 \%$ higher than those of the ethanol-treated samples, as depicted in Fig. 13a more specifically. Eventually, both recrystallization methods resulted in superior mechanical properties of PLA mats: $50-120 \%$ and 120-200\% increase in tensile strength was achieved by ethanol and heat treatment, respectively. It is assumed that a significant component of the tensile strength comes from the bonds between individual fibres, which are more characteristic for heat-treated PLA mats. This hypothesis is supported by the SEM micrographs of Fig. 2, where longitudinal adhesion of the microfibres can be evinced. The cleaning effect of solvent treatment also may have reduced the adhesion between the PLA fibres. In addition, the mean diameters of heat-treated fibres increased to $\sim 135 \%$, while that of the ethanol-treated fibres barely exceeded $115 \%$ compared to the NT mat, resulting in higher stiffness. Young's moduli $(E)$ of the samples also improved significantly, reaching twofold-threefold increase for both

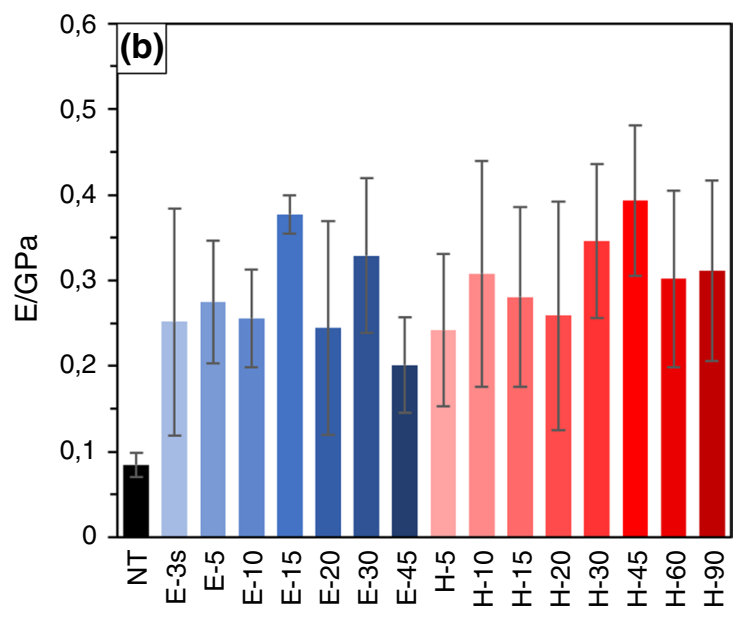

Fig. 13 Mechanical properties of nonwoven mats: a tensile strength, b Young's modulus 
crystallization routes (Fig. 13b). The notable standard deviation of the measured values may have been caused either by the differences in fibre alignment or by the varying thickness of the mat sample. In comparison, the tensile strength and Young's modulus of ethanol-treated microfibrous PLA mats prepared by Gualandi et al. [52] increased by $69 \%$ and $36 \%$, respectively. The strength of their non-treated samples was around 3.4 MPa, although this value increased only to $4.5 \mathrm{MPa}$ upon recrystallization. $\mathrm{Li}$ et al. also reported that Young's moduli of electrospun PLA mats increased with annealing time, reaching $0.4 \mathrm{GPa}$ [37].

\section{Conclusions}

Microfibrous PLA nonwoven mats were successfully manufactured by high-speed electrospinning, reaching a remarkable productivity of $40 \mathrm{~g} \mathrm{~h}^{-1}$. The effects of conventional thermal annealing and ethanol-induced crystallization were investigated on the thermal and mechanical properties, as well as on the morphology and the crystal structure of the microfibres. SEM images revealed a more dramatic relaxation of the samples treated at $85{ }^{\circ} \mathrm{C}$; on the other hand, ethanol-treated fibres mostly preserved their original shape. The fibre diameters were in the range of $0.25-8.5 \mu \mathrm{m}$ and were found to increase by 0.3 and $0.6 \mu \mathrm{m}$ as a result of solvent and heat treatment, respectively. Conventional DSC showed that solvent-induced crystallization progresses 2-3 times more rapidly; besides, the large surface-area-to-volume ratio further increases the efficiency of the methods. Differentiation between the melting of $\alpha^{\prime}$ form and recrystallization to $\alpha$ form within a single sample was accomplished using the temperature-modulated DSC method. As this effect was absent from the MDSC curves of ethanol-treated fibres, it was evinced that this technique exclusively induces the formation of the more stable $\alpha$ polymorph. Raman microspectroscopy and XRD measurements confirmed this phenomenon, allowing in-line observation of the shift between $\alpha$ and $\alpha^{\prime}$ crystalline structure. Based on the results of the LTMA measurements, superior heat resistance of both recrystallized samples was verified when compared to non-treated microfibres. Ethanol treatment resulted in fibres with a slightly higher melting temperature range due to their high $\alpha$ content. Tensile tests showed that recrystallization increased the tensile strength of the ethanol- and heat-treated nonwoven mats by $50-120 \%$ and $120-200 \%$, respectively. We also found that better structural integrity plays a key role in improved mechanical properties of the heat-treated PLA nonwovens. Recrystallized PLA nonwovens, due to their increased thermal stability and mechanical properties, are expected to find application in even wider fields.
Acknowledgements Open access funding provided by Budapest University of Technology and Economics (BME). The research was supported by the ÚNKP-18-3-I New National Excellence Program of the Ministry of Human Capacities. This work was financially supported by the Hungarian Scientific Research Fund (OTKA K112644, FK128352 and PD121171). The project was funded by the National Research, Development and Innovation Fund in the frame of NVKP 16-1-2016-0012 and GINOP-2.2.1-15-2016-00015 projects. K. Bocz is thankful for the János Bolyai Research Scholarship of the Hungarian Academy of Sciences.

\section{Compliance with ethical standards}

Conflict of interest The authors declare that they have no conflict of interest.

Open Access This article is licensed under a Creative Commons Attribution 4.0 International License, which permits use, sharing, adaptation, distribution and reproduction in any medium or format, as long as you give appropriate credit to the original author(s) and the source, provide a link to the Creative Commons licence, and indicate if changes were made. The images or other third party material in this article are included in the article's Creative Commons licence, unless indicated otherwise in a credit line to the material. If material is not included in the article's Creative Commons licence and your intended use is not permitted by statutory regulation or exceeds the permitted use, you will need to obtain permission directly from the copyright holder. To view a copy of this licence, visit http://creativecommons.org/licenses/by/4.0/.

\section{References}

1. Kalb B, Pennings AJ. General crystallization behavior of poly(L-lactic acid). Polymer. 1980;21:607-12. https://doi. org/10.1016/0032-3861(80)90315-8.

2. Mezghani K, Spruiell JE. High speed melt spinning of poly(L-lactic acid) filaments. J Polym Sci Part B Polym Phys. 1998;36:1005-12. https://doi.org/10.1002/(sici)1099-0488(19980 430)36:6\%3c1005:aid-polb9\%3e3.0.co;2-v.

3. Garlotta D. A literature review of poly(lactic acid). J Polym Environ. 2001;9:63-84. https://doi.org/10.1023/A:1020200822435.

4. Greco A, Ferrari F, Maffezzoli A. Thermal analysis of poly(lactic acid) plasticized by cardanol derivatives. J Therm Anal Calorim. 2018;134:559-65. https://doi.org/10.1007/s10973-018-7059-4.

5. Dartora PC, da Rosa Loureiro M, de Camargo Forte MM. Crystallization kinetics and morphology of poly(lactic acid) with polysaccharide as nucleating agent. J Therm Anal Calorim. 2018;134:1705-13. https://doi.org/10.1007/s10973-018-7744-3.

6. Perego G, Cella GD, Bastioli C. Effect of molecular weight and crystallinity on poly(lactic acid) mechanical properties. J Appl Polym Sci. 1996;59:37-43. https://doi.org/10.1002/(sici)10974628(19960103)59:1\%3c37:aid-app6\%3e3.0.co;2-n.

7. Carrasco F, Pagès P, Gámez-Pérez J, Santana OO, Maspoch ML. Processing of poly(lactic acid): characterization of chemical structure, thermal stability and mechanical properties. Polym Degrad Stabil. 2010;95:116-25. https://doi.org/10.1016/j.polymdegra dstab.2009.11.045.

8. Tábi T, Sajó IE, Szabó F, Luyt AS, Kovács JG. Crystalline structure of annealed polylactic acid and its relation to processing. Express Polym Lett. 2010;4:659-68. https://doi.org/10.3144/expre sspolymlett.2010.80.

9. Farah S, Anderson DG, Langer R. Physical and mechanical properties of PLA, and their functions in widespread applications-a 
comprehensive review. Adv Drug Deliv Rev. 2016;107:367-92. https://doi.org/10.1016/j.addr.2016.06.012.

10. Tábi T, Hajba S, Kovács JG. Effect of crystalline forms $\left(\alpha^{\prime}\right.$ and $\alpha$ ) of poly(lactic acid) on its mechanical, thermo-mechanical, heat deflection temperature and creep properties. Eur Polym J. 2016;82:232-43. https://doi.org/10.1016/j.eurpo lymj.2016.07.024.

11. Tábi T, Hajba S, Kovács JG. The application of the synergistic effect between the crystal structure of poly(lactic acid) (PLA) and the presence of ethylene vinyl acetate copolymer (EVA) to produce highly ductile PLA/EVA blends. J Therm Anal Calorim. 2019;138:1287-97. https://doi.org/10.1007/s10973-019-08184-x.

12. De Santis P, Kovacs AJ. Molecular conformation of poly(s-lactic acid). Biopolymers. 1968;6:299-306. https://doi.org/10.1002/ bip.1968.360060305.

13. Di Lorenzo ML. Crystallization behavior of poly(L-lactic acid). Eur Polym J. 2005;41:569-75. https://doi.org/10.1016/j.eurpo lymj.2004.10.020.

14. Eling B, Gogolewski S, Pennings AJ. Biodegradable materials of poly(L-lactic acid): 1. Melt-spun and solution-spun fibres. Polymer. 1982;23:1587-93. https://doi.org/10.1016/00323861(82)90176-8.

15. Hoogsteen W, Postema AR, Pennings AJ, Ten Brinke G, Zugenmaier P. Crystal structure, conformation and morphology of solution-spun poly(L-lactic acid) fibers. Macromolecules. 1990;23:634-42. https://doi.org/10.1021/ma00204a041.

16. Puiggali J, Ikada Y, Tsuji H, Cartier L, Okihara T, Lotz B. The frustrated structure of poly(L-lactide). Polymer. 2000;41:892130. https://doi.org/10.1016/S0032-3861(00)00235-4.

17. De Oca HM, Ward IM. Structure and mechanical properties of poly(L-lactic acid) crystals and fibers. J Polym Sci Part B Polym Phys. 2007;45:892-902. https://doi.org/10.1002/polb.21131.

18. Wang H, Zhang J, Tashiro K. Phase transition mechanism of poly(L-lactic acid) among the $\alpha, \delta$, and $\beta$ forms on the basis of the reinvestigated crystal structure of the $\beta$ form. Macromolecules. 2017;50:3285-300. https://doi.org/10.1021/acs.macro mol.7b00272.

19. Cartier L, Okihara T, Ikada Y, Tsuji H, Ouiggali J, Lotz B. Epitaxial crystallization and crystalline polymorphism of polylactides. Polymer. 2000;41:8909-19. https://doi.org/10.1016/ S0032-3861(00)00234-2.

20. Zhang J, Duan Y, Sato H, Tsuji H, Noda I, Yan S, Ozaki Y. Crystal modifications and thermal behavior of poly(L-lactic acid) revealed by infrared spectroscopy. Macromolecules. 2005;38:8012-21. https://doi.org/10.1021/ma051232r.

21. Kawai T, Rahman N, Matsuba G, Nishida K, Kanaya T, Nakano M, Okamoto H, Kawada J, Usuki A, Honma N, Nakajima K, Matsuda M. Crystallization and melting behavior of poly(Llactic acid). Macromolecules. 2007;40:9463-9. https://doi. org/10.1021/ma070082c.

22. Zhang J, Tashiro K, Tsuji H, Domb AJ. Disorder-to-order phase transition and multiple melting behavior of poly(L-lactide) investigated by simultaneous measurements of WAXD and DSC. Macromolecules. 2008;41:1352-7. https://doi. org/10.1021/ma0706071.

23. Cocca M, Di Lorenzo ML, Malinconico M, Frezza V. Influence of crystal polymorphism on mechanical and barrier properties of poly(L-lactic acid). Eur Polym J. 2011;47:1073-80. https:// doi.org/10.1016/j.eurpolymj.2011.02.009.

24. Righetti MC, Gazzano M, Di Lorenzo ML, Androsch R. Enthalpy of melting of $\alpha^{\prime}$ - and $\alpha$-crystals of poly(L-lactic acid). Eur Polym J. 2015;70:215-20. https://doi.org/10.1016/j.eurpo lymj.2015.07.024.

25. Wen P, Zhu DH, Feng K, Liu FJ, Lou WY, Li N, Zhong MH, Wu H. Fabrication of electrospun polylactic acid nanofilm incorporating cinnamon essential oil/ $\beta$-cyclodextrin inclusion complex for antimicrobial packaging. Food Chem. 2016;196:996-1004. https://doi.org/10.1016/j.foodchem.2015.10.043.

26. Aytac Z, Keskin NOS, Tekinay T, Uyar T. Antioxidant $\alpha$-tocopherol $/ \gamma$-cyclodextrin-inclusion complex encapsulated poly(lactic acid) electrospun nanofibrous web for food packaging. J Appl Polym Sci. 2017;134:44858. https://doi.org/10.1002/ app.44858.

27. Liu Y, Cheng B, Cheng G. Development and filtration performance of polylactic acid meltblowns. Text Res J. 2009;80:7719. https://doi.org/10.1177/0040517509348332.

28. Wang Z, Pan Z. Preparation of hierarchical structured nanosized/porous poly(lactic acid) composite fibrous membranes for air filtration. Appl Surf Sci. 2015;356:1168-79. https://doi. org/10.1016/j.apsusc.2015.08.211.

29. Xiang C, Frey MW, Taylor AG, Rebovich ME. Selective chemical absorbance in electrospun nonwovens. J Appl Polym Sci. 2007;106:2363-70. https://doi.org/10.1002/app.26587.

30. Chen PY, Tung SH. One-step electrospinning to produce nonsolvent-induced macroporous fibers with ultrahigh oil adsorption capability. Macromolecules. 2017;50:2528-34. https://doi. org/10.1021/acs.macromol.6b02696.

31. Herrero-Herrero M, Gómez-Tejedor JA, Vallés-Lluch A. PLA/ PCL electrospun membranes of tailored fibres diameter as drug delivery systems. Eur Polym J. 2017;99:445-55. https://doi. org/10.1016/j.eurpolymj.2017.12.045.

32. Nagy ZK, Balogh A, Démuth B, Pataki H, Vigh T, Szabó B, Molnár K, Schmidt BT, Horák P, Marosi G, Verreck G, Van Assche I, Brewster ME. High speed electrospinning for scaled-up production of amorphous solid dispersion of itraconazole. Int J Pharma. 2015;480:137-42. https://doi.org/10.1016/j.ijpharm.2015.01.025.

33. Démuth B, Farkas A, Pataki H, Balogh A, Szabó B, Borbás E, Sóti PL, Vigh T, Kiserdei É, Farkas B, Mensch J, Verreck G, Van Assche I, Marosi G, Nagy ZK. Detailed stability investigation of amorphous solid dispersions prepared by single-needle and high speed electrospinning. Int J Pharma. 2016;498:234-44. https:// doi.org/10.1016/j.ijpharm.2015.12.029.

34. Bye FJ, Wang L, Bullock AJ, Blackwood KA, Ryan AJ, MacNeil S. Postproduction processing of electrospun fibres for tissue engineering. J Vis Exp. 2012;66:e4172. https://doi.org/10.3791/4172.

35. Kang Y, Wang C, Qiao Y, Gu J, Zhang H, Peijs T, Kong J, Zhang $\mathrm{G}$, Shi $\mathrm{X}$. Tissue-engineered trachea consisting of electrospun patterned sc-PLA/GO-g-IL fibrous membranes with antibacterial property and 3D-printed skeletons with elasticity. Biomacromol. 2019;20:1765-76. https://doi.org/10.1021/acs.biomac.9b00160.

36. Tan EPS, Lim CT. Effects of annealing on the structural and mechanical properties of electrospun polymeric nanofibers. Nanotechnology. 2006;17:2649-54. https://doi. org/10.1088/0957-4484/17/10/034.

37. Li L, Hashaikeh R, Arafat HA. Development of eco-efficient micro-porous membranes via electrospinning and annealing of poly(lactic acid). J Membrane Sci. 2013;436:57-67. https://doi. org/10.1016/j.memsci.2013.02.037.

38. Vadas D, Kmetykó D, Marosi G, Bocz K. Application of meltblown poly(lactic acid) fibres in self-reinforced composites. Polymers. 2018;10:1-12. https://doi.org/10.3390/polym10070766.

39. Rezabeigi E, Wood-Adams PM, Demarquette NR. Complex morphology formation in electrospinning of binary and ternary poly(lactic acid) solutions. Macromolecules. 2018;51:4094-107. https://doi.org/10.1021/acs.macromol.8b00083.

40. Szabó E, Démuth B, Nagy B, Molnár K, Farkas A, Szabó B, Balogh A, Hirsch E, Nagy B, Marosi G, Nagy ZK. Scaled-up preparation of drug-loaded electrospun polymer fibres and investigation of their continuous processing to tablet form. Express Polym Lett. 2018;12:436-51. https://doi.org/10.3144/expresspol ymlett.2018.37. 
41. Vass P, Démuth B, Farkas A, Hirsch E, Szabó E, Nagy B, Andersen SK, Vigh T, Verreck G, Csontos I, Marosi G, Nagy ZK. Continuous alternative to freeze drying: manufacturing of cyclodextrin-based reconstitution powder from aqueous solution using scaled-up electrospinning. J Control Release. 2019;298:120-7. https://doi.org/10.1016/j.jconrel.2019.02.019.

42. Farkas B, Balogh A, Cselkó R, Molnár K, Farkas A, Borbás E, Marosi G, Nagy ZK. Corona alternating current electrospinning: a combined approach for increasing the productivity of electrospinning. Int J Pharma. 2019;561:219-27. https://doi.org/10.1016/j. ijpharm.2019.03.005.

43. Sánchez-Arévalo FM, Muñoz-Ramírez LD, Álvarez-Camacho M, Rivera-Torres F, Maciel-Cerda A, Montiel-Campos R, Vera-Graziano R. Macro- and micro-mechanical behaviors of poly(lactic acid)-hydroxyapatite electrospun composite scaffolds. J Mater Sci. 2017;52:3353-67. https://doi.org/10.1007/ s10853-016-0624-y.

44. Huan S, Liu G, Cheng W, Han G, Bai L. Electrospun poly(lactic acid)-based fibrous nanocomposite reinforced by cellulose nanocrystals: impact of fiber uniaxial alignment on microstructure and mechanical properties. Biomacromol. 2018;19:1037-46. https ://doi.org/10.1021/acs.biomac.8b00023.

45. Tsuji H, Nakano M, Hashimoto M, Takashima K, Katsura S, Mizuno A. Electrospinning of poly(lactic acid) stereocomplex nanofibers. Biomacromol. 2006;7:3316-20. https://doi. org/10.1021/bm060786e.

46. Pan G, Xu H, Ma B, Wizi J, Yang Y. Polylactide fibers with enhanced hydrolytic and thermal stability via complete stereocomplexation of poly(L-lactide) with high molecular weight of 600000 and lower-molecular-weight poly(D-lactide). J Mater Sci. 2018;53:5490-500. https://doi.org/10.1007/s10853-017-1944-2.

47. Tashiro K, Kouno N, Wang H, Tsuji H. Crystal structure of poly(lactic acid) stereocomplex: random packing model of PDLA and PLLA chains as studied by X-ray diffraction analysis. Macromolecules. 2017;50:8048-65. https://doi.org/10.1021/acs.macro mol.7b01468.

48. Aou K, Kang S, Hsu SL. Morphological study on thermal shrinkage and dimensional stability associated with oriented poly(lactic acid). Macromolecules. 2005;38:7730-5. https://doi.org/10.1021/ ma051022e.

49. Ribeiro C, Sencadas V, Costa CM, Gómez Ribelles JL, LancerosMéndez S. Tailoring the morphology and crystallinity of poly(Llactide acid) electrospun membranes. Sci Technol Adv Mater. 2011;12:015001. https://doi.org/10.1088/1468-6996/12/1/015001.

50. Viswanath V, Maity S, Bochinski JR, Clarke LI, Gorga RE. Enhanced crystallinity of polymer nanofibers without loss of nanofibrous morphology via heterogeneous photothermal annealing. Macromolecules. 2016;49:9484-92. https://doi.org/10.1021/ acs.macromol.6b01655.

51. Naga N, Yoshida Y, Inui M, Noguchi K, Murase S. Crystallization of amorphous poly(lactic acid) induced by organic solvents. J Appl Polym Sci. 2010;119:2058-64. https://doi.org/10.1002/ app.32890.

52. Gualandi C, Govoni M, Foroni L, Valente S, Bianchi M, Giordano E, Pasquinelli G, Biscarini F, Focarete ML. Ethanol disinfection affects physical properties and cell response of electrospun poly(Llactic acid) scaffolds. Eur Polym J. 2012;48:2008-18. https://doi. org/10.1016/j.eurpolymj.2012.09.016.

53. Somord K, Suwantong O, Tawichai N, Peijs T, Soykeabkaew N. Self-reinforced poly(lactic acid) nanocomposites of high toughness. Polymer. 2016;103:347-52. https://doi.org/10.1016/j.polym er.2016.09.080.

54. Solarski S, Ferreira M, Devaux E. Characterization of the thermal properties of PLA fibres by modulated scanning calorimetry. Polymer. 2005;46:11187-92. https://doi.org/10.1016/j.polym er.2005.10.027.
55. Knopp MM, Löbmann K, Elder DP, Rades T, Holm R. Recent advances and potential applications of modulated differential scanning calorimetry (mDSC) in drug development. Eur J Pharm Sci. 2016;87:164-73. https://doi.org/10.1016/j.ejps.2015.12.024.

56. Schawe JEK, Hütter T, Heitz C, Alig I, Lellinger D. Stochastic temperature modulation: a new technique in temperature-modulated DSC. Thermochim Acta. 2006;446:147-55. https://doi. org/10.1016/j.tca.2006.01.031.

57. Chen K, Wilkie CA, Vyazovkin S. Nanoconfinement revealed in degradation and relaxation studies of two structurally different polystyrene-clay systems. J Phys Chem. B. 2007;111:12685-92. https://doi.org/10.1021/jp0759168.

58. Fraga I, Montserrat S, Hutchinson JM. TOPEM, a new temperature modulated DSC technique. J Therm Anal Calorim. 2007;87:119-24. https://doi.org/10.1007/s10973-006-7969-4.

59. Wasanasuk K, Tashiro K, Hanesaka M, Ohhara T, Kurihara K, Kuroki R, Tamada T, Ozeki T, Kanamoto T. Crystal structure analysis of poly(L-lactic acid) $\alpha$ form on the basis of the 2-dimensional wide-angle synchrotron X-ray and neutron diffraction measurements. Macromolecules. 2011;44:6441-52. https://doi. org/10.1021/ma2006624.

60. Yang X, Kang S, Yang Y, Aou K, Hsu SL. Raman spectroscopic study of conformational changes in the amorphous phase of poly(lactic acid) during deformation. J Polym Sci Part B Polym Phys. 2011;49:1146-454. https://doi.org/10.1016/j.polym er.2004.03.107.

61. Kalish JP, Aou K, Yang X, Hsu SL. Spectroscopic and thermal analyses of $\alpha^{\prime}$ and $\alpha$ crystalline forms of poly(L-lactic acid). Polymer. 2011;52:814-21. https://doi.org/10.1016/j.polym er.2010.12.042.

62. Chen X, Kalish JP, Hsu SL. Structure evolution of $\alpha^{\prime}$-phase poly(lactic acid). J Polym Sci Part B Polym Phys. 2011;49:144654. https://doi.org/10.1002/polb.22327.

63. Pollock HM, Hammiche A. Micro-thermal analysis: techniques and applications. J Phys D Appl Phys. 2001;34:R23-53. https:// doi.org/10.1088/0022-3727/34/9/201.

64. Price DM, Reading M, Hammiche A, Pollock HM, Branch MG. Localised thermal analysis of a packaging film. Thermochim Acta. 1999;332:143-9. https://doi.org/10.1016/S0040-6031(99)00068 $-4$.

65. Moon I, Androsch R, Chen W, Wunderlich B. The principles of micro-thermal analysis and its applications to the study of macromolecules. J Therm Anal Calorim. 2000;59:187-203. https://doi. org/10.1023/A:1010144230796.

66. Van Assche G, Van Mele B. Interphase formation in model composites studied by micro-thermal analysis. Polymer. 2002;43:4605-10. https://doi.org/10.1016/S0032-3861(02)00298 $-7$.

67. Le Marec PE, Ferry L, Quantin JC, Benezet JC, Bonfils F, Guilbert $\mathrm{S}$, Bergeret $\mathrm{A}$. Influence of melt processing conditions on poly(lactic acid) degradation: molar mass distribution and crystallization. Polym Degrad Stabil. 2014;110:353-63. https://doi. org/10.1016/j.polymdegradstab.2014.10.003.

68. Fischer EW, Sterzel HJ, Wegner G. Investigation of the structure of solution grown crystals of lactide copolymers by means of chemical reactions. Kolloid Z Z Polym. 1973;251:980-90. https ://doi.org/10.1007/BF01498927.

69. Kong W, Tong B, Ye A, Ma R, Gou J, Wang Y, Liu C, Shen C. Crystallization behavior and mechanical properties of poly(lactic acid)/poly(ethylene oxide) blends nucleated by a self-assembly nucleator. J Therm Anal Calorim. 2019;135:3107-14. https://doi. org/10.1007/s10973-018-7528-9.

Publisher's Note Springer Nature remains neutral with regard to jurisdictional claims in published maps and institutional affiliations. 